\title{
MUSLIM SOSIAL DALAM DUA FILM NURMAN HAKIM
}

\author{
Makbul Mubarak
}

\begin{abstract}
Abstrak : Sejak dirilisnya film Al-Kautsar (1975), film bercorak Islam mulai tumbuh subur di Indonesia dengan dipuncaki oleh kejayaan film-film Rhoma Irama yang menggabungkan dakwah Islam dan musik dangdut . Setelah Reformasi 1998 dan pasca bangun kembalinya Industri film Indonesia, film Islam kembali tumbuh dengan dipelopori oleh suksesnya Ayat-Ayat Cinta (2005) di pasaran. Beberapa penelitian terdahulu seperti Terdapat perbedaan corak antara film-film Islam sebelum 1998 dan setelah 1998. Sebelum 1998, film-film dakwah senantiasa menggunakan Islam sebagai alat mencapai kemaslahatan sosial, sementara setelahnya, film-film Islam cenderung individualis. Makalah ini memeriksa kembali dikotomi yang sudah dibangun ini dengan mendeteksi jejak-jejak konseptualisasi muslim sosial dalam film-film Islam masa kini.
\end{abstract}

Key words : film Islam, film dakwah, pemberdayaan sosial, individualisme, Orde Baru, pasca-Orde Baru/pasca-reformasi.

\section{Pendahuluan}

Dalam penelitian Sasono (2011), ia mengemukakan bahwa terdapat perbedaan antara corak film-film Islam yang dibuat di masa Orde Baru dan setelah Orde Baru berakhir. Perbedaan itu terutama terletak pada kecenderungan film-

Makbul Mubarak adalah Staf Pengajar pada Fakultas Seni Rupa dan Desain, Universitas Multimedia Nusantara (UMN) Tangerang. film Islam di masa Orde Baru untuk menggunakan Islam sebagai alat untuk menyelesaikan permasalahan bersama. Misalnya, Sasono memberi contoh, dalam film seperti Nada dan Dakwah (1991), Zaenuddin MZ bahu-membahu dengan Rhoma Irama untuk membantu penduduk setempat untuk mempertahankan tanah mereka dari kon-

e-mail : makbul@umn.ac.id 
glomerat yang ingin membeli paksa. Corak-corak seperti ini kemudian berubah diera setelah tumbangnya OrdeBaru.

Rahman (2011) mencatat bahwa dalam film-film Islam pasca Orde Baru, misalnya seperti yang secara percontohan diperlihatkan oleh AyatAyat Cinta (2005), Islam kemudian semakin personal dan tidak lagi digunakan untuk menyelesaikan masalah sosial. Islam kemudian dibatasi pada masalah pribadi seperti mencari jodoh, sukses dalam bisnis, sekolah ke luar negeri dan sebagainya.

Makalah ini bermaksud memeriksa kembali dikotomi oleh Sasono (2011) dan Rahman (2011). Apakah dikotomi yang dikemukakan oleh mereka memang sehitam-putih adanya? Apakah film Islam bertema sosial nihil di era pasca-Orde Baru? Bila ada, apakah pola presentasi problemnya masih sama dengan yang sebelumnya? Isu-isu apa saja yang direpresen-tasikan oleh film-film itu?

\section{Metodologi}

Metode yang digunakan dalam penelitian ini adalah pemilihan studi kasus dengan merujuk pada film-film Islam yang dibuat pada pasca Orde Baru. Untuk kepentingan ini, film-film Habiburrahman El-Shirazy, beberapa film yang diproduksi oleh Kelompok Mizan, serta film-film Nurman Hakim dapat kita kategorikan sebagai film Islam.

Dalam pemilihan objek penelitian, film-film Habiburrahman El-Shirazy kemudian dieliminasi oleh sebab karakter naratifnya yang cocok dengan amatan Rahman: penggunaan Islam untuk kepentingan individu. Dalam beberapa film produksi Kelompok Mizan seperti Laskar Pelangi (2007), Sang Pemimpi (2009), serta Semesta Mendukung (2011), Islam hadir namun hanya sebagai latar belakang (backdrop) cerita dan bukan kata kunci dari tata tuturnya. Beberapa film Kelompok Mizan seperti 3 Hati 2 Dunia, 1 Cinta (2010) bahkan terang-terangan menggunakan agama sebagai aral dalam romantika personal.

Film yang dipilih sebagai objek penelitian dalam makalah ini adalah dua film Nurman Hakim yakni 3 Doa 3 Cinta (2008) dan Khalifah (2011). Nurman Ha-kim dipilih karena ia murni aktif beroperasi sebagai sutradara pasca runtuhnya Orde Baru, yang berarti ia tidak bersinggungan dengan sistem produksi dan industri film masa itu setidaknya tidak sebagai sutradara, berikutnya oleh sebab dua film pertamanya secara konsisten membahas persoalan Islam ketika bersinggungan dengan individu dan ruang sosial dan bukan saja bersinggungan dengan yang personal. Penjelasan detil mengenai hal ini akan kita jelajahi lebih jauh dalam pembahasan. 


\section{Kerangka besar persoalan}

Sebagai bangsa dengan populasi pemeluk Islam terbesar di dunia, rasanya tidak mengherankan apabila budaya populer di Indonesia sangat sering hadir dalam corak yang dekat dengan budaya Islam. Sejak zaman Orde Baru, simbol-simbol keis-laman sudah sangat sering dipakai dalam film yang kemudian menjadi tontonan khalayak ramai. Misalnya, sempat ditinjau oleh Van Heeren (2007), bahwa dalam film-film horor, kyai kerap dipakai sebagai ajian terakhir untuk mengusir setan dan menyelesaikan konflik. Kyai menjadi jalan terakhir setelah segala macam usaha dilakukan untuk mengusir sang dedemit gagal. Pada zaman Orde Baru pula, film-film bertemakan perjuangan kemerdekaan santer sekali menggunakan simbol keislaman sebagai semangat tandingan melawan penjajah belanda. Dalam film Pahlawan Goa Selarong (1972), Diponegoro sebagai tokoh sentral digambarkan sebagai pahlawan nasional yang piawai mengatur strategi perang, lebih dari itu, ia juga digambarkan sebagai sosok yang taat beribadah. Diponegoro diselimuti oleh embun keis-laman di setiap ruang kalbunya.

Kehadiran Islam dalam film tidak hanya diwujudkan lewat penyatuannya dengan genre-genre tertentu seperti horor dan film bertemakan perjuangan, sejak dekade 1980-an, Islam bahkan membentuk semacam corak naratifnya sendiri. Dalam film Titian Serambut Dibelah Tujuh (1982), seorang guru datang ke desa yang perilaku penduduknya telah sesat menyerupai kaum nabi Luth (versi Al-qur'an). Sontak, naluri pendidik sang guru mengajaknya turun ke medan juang guna mengembalikan perilaku masyarakat agar kembali ke ajaran Islam yang benar. Perjuangan tersebut tidak mudah, sebab perilaku masyarakat ini sudah terlembaga sedemikian rapatnya sehingga sulit merunut pangkal problemanya.

Dalam film Nada dan Dakwah (1992), musisi dangdut Rhoma Irama mendatangi sebuah desa. Rhoma Irama adalah legenda musik dangdut yang karirnya tidak saja sangat bersinar dalam blantika musik, melainkan juga merembet ke dunia lakon. Tak kurang dari sepuluh film dibintanginya, semuanya menampilkan Rhoma sebagai Rhoma Irama si raja dangdut, dan semuanya laku keras. Bersama Rhoma, datang pula Kyai Haji Zainuddin MZ, muballigh kondang yang pada masa itu juga memiliki tingkat penjualan kaset yang tinggi. Rhoma dan Zainuddin bahu-membahu membangun desa, Rhoma bertugas mengayomi masyarakat dalam bidang keduniawian, sementara Zainuddin membantu dalam hal kerohanian. 
Kritikus film Eric Sasono (2011) menyebut bahwa ada beberapa film penting yang sarat dengan tema pembaruan Islam pada masa Orde Baru. Pembaharuan ini, sadar atau tidak sadar, sejalan dengan pemikiran Islam kultu- ral yang sangat berpengaruh di Indonesia pada era yang bersamaan. Eric menyematkan sebuah kriteria penting untuk memaknai pembaruan, yakni relevansi keberagamaan (yang disebut sebagai aras intelektual) dalam rangka memahami dan memecahkan permasalahan bersama (aras sosial). Meminjam konsepsi pemikir Ignas Kleden, Eric menekankan bahwa pembaharuan haruslah memiliki relevansi tidak hanya dengan buah-buah intelektualitas yang berbunga dalam buku, melainkan juga relevansinya atas permasalahan kolektif yang pula harus selesai dalam tingkat kolektif alias tidak hanya selesai pada tingkat individu. Pada beberapa film, ternyata para karakter utama tidak hanya menjalankan agama mereka sebagai urusan pribadi dengan tuhan, melainkan juga secara terus-menerus berusaha memahami konteks agama (aras intelektual) untuk diselaraskan dengan ruang bersama (aras sosial).

Definisi Eric terhadap pembaharuan Islam dalam film tentu saja secara otomatis menggugurkan peran kiai dalam film-film horor. Kiai dalam film horor berhasil mengusir setan hanya dengan membacakan beberapa ayat dari Al-quran, yang secara fungsional lebih menyerupai mantra-mantra gaib (yang sudah dikenal di Indonesia sejak zaman pra-Islam), dan tidak melalui prosuder-prosedur intelektual. Para kiai dalam film-film horor ini sekedar mengganti teks mantra-mantra gaib pra-Islam dengan teks Al Quran yang kemudian berefek sama, yakni rontoknya perlawanan tokoh jahat. Ayat yang di-bacakan oleh sang kiai tiba-tiba bisa menyelesaikan permasalahan, tidak jarang bahkan berhasil menyelesaikan prahara sosial di suatu kampung. Yang berbeda di antara peran agama dalam film-film horor dan peran agama dalam film-film yang bertemakan pembaruan terletak pada relevansi intelektualnya. Film-film pembaharuan lebih menekankan pada prosedur intelektual sementara filmfilm horor menerapkan yang sebaliknya.

Dalam amatan Eric, Nada dan Dakwah (1992) adalah film terakhir yang bertemakan pembaruan yang dibuat pada masa Orde Baru, sebab setelahnya, Indo-nesia menderita mati lampu industri film. Perfilman Indonesia sayupsayup tak terdengar antara tahun 1993 dan 1998. Ketika listrik perfilman menyala kembali pada tahun 1999, filmfilm bertemakan Islam pun perlahan-lahan dibuat kembali. Puncaknya ketika 
film Ayat-Ayat Cinta (2005) mereguk ge-lar blockbuster dengan meraih predikat terlaris pada tahun rilisnya.

Kritikus Lisabona Rahman (2011) mencatat bahwa ada pergeseran ruang rambahan pada film-film bertemakan Islam di era Orde Baru dengan film-film berte-makan Islam yang dibuat di era Reformasi . Menjadikan Ayat-Ayat Cinta sebagai studi kasus, Lisabona mencatat bahwa Islam yang dulunya bergerak dalam ruang sosial, digunakan untuk menyelesaikan masalah dalam ruang sosial, kini mengkerut dan beringsut masuk ke ruang personal. Islam kemudian digunakan sebagai pemecah masalah personal, lebih spesifik lagi, masalah cinta. Dalam Ayat-Ayat Cinta,Fahri adalah tokoh yang sangat taat dalam beragama dan digambarkan cenderung abai terhadap kehidupan duniawi. Tasnya tak pernah ia ganti sejak SMA, selalu minder bila bertemu wanita, tapi sangat taat beribadah dan lamun wawasan agamanya. Walhasil ia berhasil mempersunting (atau lebih tepatnya, dipersunting) oleh Aisha, seorang perempuan kaya yang juga muslimah. Seiring berjalannya cerita, Fahri mendapat satu isteri lagi, yaitu Maria, tetangganya yang menganut kristen koptik. Bukan Fahri yang menginginkan Aisha dan Maria, tetapi merekalah yang menginginkan Fahri. Di sini, Islam kemudian hadir sebagai senjata utama bagi siapapun yang sedang mencari jodoh. Perbaiki agama- $\mathrm{mu}$, niscaya akan langgeng jodohmu. Ayat-Ayat Cinta memulai tren film-film bertemakan Islam pasca-Soeharto, dimana Islam kemudian dijadi-kan piranti utama dalam memenuhi hasrat asmara. Ia menjadi kriteria krusial tokoh utama untuk jatuh cinta dan menikah. Permasalahan yang bisa diselesaikan Islam kemudian menyempit. Dulunya, Islam bisa menyelesaikan permasalahan sosial yang berlapis-lapis untuk kepentingan bersama, sekarang Islam hanya bisa menyelesaikan masalah personal. Pencapaian agamis bukan lagi pencapaian kolektif yang selaras dengan intelektualitas, melainkan sebagai pencapaian individu yang terlena dalam semesta-semesta romantis. Islam dalam film-film semacam ini hanya masuk pada gaya hidup per-mukaan, seperti pakaian, lokasi (setting Cerita Ayat-Ayat Cinta berlokasi di Mesir, diikuti oleh film-film lain dan bahkan merambat ke tayangan televisi, seperti Kupinang Kau Dengan Bismillah, tayang di SCTV, yang mengambil latar cerita di Turki). Pendek kata, film-film bertemakan Islam di Indonesia pasca-Soeharto, sedikit banyak, kehilangan kekuatan pembaruannya.

Posisi sosial Islam mengalami perubahan tajam menyusul tumbangnya rezim Orde Baru tahun 1998. Islam yang dulunya bernaung di bawah supremasi nasionalisme kini mendapatkan ruang 
gerak yang lebih leluasa. Partai Islam PPP yang dulunya adalah partai anak bawang yang berteduh di bawah ketiak Golkar kini punya momentum untuk merekrut massanya sendiri. Salah satu perubahan sosial yang utama adalah perubahan posisi politik jilbab dalam kaitannya dengan boleh tidaknya jilbab masuk ke ruang publik. Alatas (2008) mencatat bahwa di era Orde Baru, tepatnya setelah SK 052 tentang larang berjilbab dimaklumatkan oleh De-partemen $\mathrm{P}$ dan $\mathrm{K}$ tahun 1982, para perempuan pemeluk Islam dilarang mengenakan jilbab ke sekolah sebab sekolah sedianya berperan sebagai media penempa siswa dalam rangka menjadi seorang nasionalis, bukan agamis. Kementrian bahkan menggelar rapat khusus dengan Majelis Ulama Indonesia (MUI) untuk menegaskan kembali bahwa seragam seyogyanya menyeragamkan siswa, maka bila ada siswa yang memakai jilbab dan ada yang tidak, maka seragam tak dapat lagi disebut seragam.

Polemik jilbab ini dengan cergas dikapsulkan oleh film Kantata Takwa (yang baru dirilis secara resmi tahun 2008 padahal sudah mulai diproduksi sejak tahun 1990), dimana jilbab menjadi simbol perlawanan atas kesewenangan rezim Soeharto yang menutup pipa-pipa ekspresi publik pemeluk Islam. Pasca Orde Baru, jilbab yang awalnya direpresi oleh rezim menjadi ramai muncul ke publik. Sekolah memperbolehkan siswi pemeluk Islam untuk mengenakan jilbab ke sekolah. Kebijakan otonomi daerah yang memungkinkan setiap provinsi untuk mengatur kebijakan hukumnya sendiri berdampak besar pada posisi jilbab di sejumlah daerah. Di Provinsi Nanggroe Aceh Darussalam (NAD), pemerintah merekrut 2.500 orang untuk bertugas se-bagai polisi syariah dalam rangka implementasi hukum Islam, para siswi bukan lagi diperbolehkan, melainkan diwajibkan untuk memakai jilbab ke sekolah tak peduli apapun agama mereka. Setiap wanita yang melancong ke Aceh diwajibkan mengenakan jilbab selama mereka berada di wilayah itu.

Tidak hanyaitu,jilbabjuga kemudian menjadi tren di kalangan publik. Islam yang sebelumnya tertekan oleh rezim kini dengan bebas mengekspresikan diri mereka di ruang publik. Sinetron-sinetron berbau Islam bertampilan di televisi. Nada dering yang dikutip dari tilawah alquran ramai diperdagangkan. Ormas Islam mendapat posisi politik yang semakin kuat. Dalam aspek sinema, Ayat-Ayat Cinta arahan Hanung Bramantyo dinobatkan menjadi film terlaris di tahun rilisnya, ia diadaptasi dari novel berjudul sama yang juga meraup predikat best seller. Dalam seni 
sastra, Komunitas penulis Forum Lingkar Pena menjadi keran utama produksi novel-novel berbau Islam. Habiburrahman El-Shirazy, penulis novel AyatAyat Cinta adalah alumni komunitas ini. Nantinya, novel Habiburrahman juga diadaptasi ke film Ketika Cinta Bertasbih 1 dan 2, lalu juga Dalam Mihrab Cinta yang diarahkan olehnya sendiri.

Tren yang dimulai oleh Habiburrahman juga diikuti oleh banyak sekali film lain, seperti Syahadat Cinta (2008), Hafalan Shalat Delisha (2011) dan banyak lagi film serupa, dan masih dipelihara oleh Habiburrahman di film terbaru dari novel yang ditulisnya, Cinta Suci Zahrana (2012). Segerombolan film ini membentuk tren baru yang temanya mengu-langi tren film-film "pembaharuan islam" pada pasca Orde Baru. Meskipun demikian, kesamaan tema belum tentu mengindikasikan kesamaan sudut pandang. Berbeda dengan posisi islam yang nomor dua pada masa Orde Baru sehingga "mengatasi permasalahan sosial dengan cara islam" dianggap perlu untuk diangkat terus menerus dalam film, dalam rangka menyaingi "cara mengatasi permasalahan sosial dengan cara negara dalam rangka pembangunan" yang dipromosikan oleh rezim, film-film bertemakan islam pasca-Soeharto justru merupakan affirmasi bahwa islam telah menjadi fondasi keseharian masyarakat. Semua karakter dalam film Habiburrahman senantiasa bersentuhan dengan Islam. Salah satu karakter bernama Maria yang memeluk koptik dalam Ayat-Ayat Cinta, ternyata hafal Surat Maryam di luar kepala.

Ironisnya, dalam film-film bertemakan Islam pasca Orde Baru, affirmasi bahwa Islam kini telah menjadi kekuatan posisi (dan bukan lagi oposisi, sekunder, dan tertekan) justru menggiring narasi-narasi film untuk menjauh dari ruang publik. Dalam ketiga film Habiburrahman, atribut keislaman sang protagonis ternyata lebih mempengaruhinya dalam proses menemukan pasangan romantika dibanding mengaplikasikannya ke ruang publik. Kadar-kadar keislaman yang masih bernilai untuk dipertaruhkan justru menyusut jauh ke dalam ruang personal dan tidak lagi digunakan untuk menelaah permasalahan-permasalahan publik seperti yang terdapat dalam filmfilm berte-makan Islam di masa Orde Baru. Tak ada lagi Kiai yang datang ke kampung untuk mengajar cara bercocok tanam. Sekarang, seorang yang taat beragama akan mendapat istri yang kaya, cantik, dan tentu saja solehah.

Ruang publik kemudian menjadi steril dari konflik naratif sebab telah dipandang sebagai sesuatu yang sudah otomatis akan mengkonfirmasi kesahihan Islam. Islam yang dulunya senantiasa dipandang sebagai atribut perlawanan sekarang telah berubah menjadi kekua- 
tan posisi yang default dan cenderung menindas kekuatan-kekuatan sosial lain yang lebih kecil. Puncaknya kemudian terjadi pada dua tahun terakhir dimana kekuatan-kekuatan sosial politik Islam di Indonesia mulai menjurus pada hal-hal xenophobic: menghalangi umat kristen membangun gereja, bahkan merajam sesama muslim yang dinilai memiliki secabang dua ajaran melenceng, misalnya konflik Ahmadiyah yang meletus di Cikeusik tahun 2011 silam.

Ruang publik yang senantiasa konfirmatif terhadap Islam tak lagi strategis untuk disentuh oleh narasi-narasi film bertemakan Islam, tak ada lagi yang dilawan dalam ruang publik tersebut, sehingga film tentang agama kian berkisar di seputar romantika pribadi para pemeluknya. Temuan ini terdengar menarik karena seolah menandakan bahwa orang semakin toleran, mereka tak lagi pusing memikirkan agama orang lain. Agama kemudian menjadi urusan yang pribadi antara hamba dan tuhan. Namun, menyusutnya narasi film bertemakan Islam ke ruang-ruang semacam itu ternyata bukanlah affirmasi atas berkembangnya toleransi beragama, melainkan menjadi sebentuk wujud pengabaian atas ruang sosial yang bukannya semakin tenang dan toleran, tapi tetap saja bergolak disebabkan oleh aplikasi-aplikasi agama yang cenderung memaksa, bahkan seringkali memuncak pada aksi kekerasan berskala dunia, ambil contoh seri Bom Bali dan serangkaian kekerasan atas nama agama oleh ormas-ormas Islam konservatif. Polemik islam yang tersisa di ruang publik kemudian tidak terpotret oleh sebagian besar film-film bertemakan Islam pasca Orde Baru. Semangat pembaharuan tidak turut serta ke dalam narasi film-film Islam box office itu.

\section{Nurman Hakim}

Sebagai pembuat film, Nurman Hakim kalah tenar dibanding istrinya, Nan Achnas, yang membuat film-filmarthouse yang juga dikenal baik oleh publik macam Kuldesak (1997), Pasir Berbisik (200o), dan The Photograph. (2007) Nurman baru membuat film pertamanya tahun 2008, sebuah cerita comingof-age yang berlangsung di pesantren yang diberi judul 3 Doa 3 Cinta (2008). Tiga melambangkan jumlah karakter utama: Huda (Nicholas Saputra), anak pesan- tren ganteng yang senantiasa mencari tahu dimana rimba ibunya yang menitipkannya di Pesantren lalu pergi tak berbekas sebelas tahun yang lalu. Dari pesantren kecilnya di pinggir Yogyakarta, Huda mendamba Jakarta. Di sanalah konon ibunya pergi mengembara mencari nafkah. Setiap receh yang dikumpulkannya ditabung untuk suatu 
saat digunakan sebagai ongkos pergi menelusuri kerlipan misterius Jakarta di dalam kepalanya. Saat kegelisahannya memuncak, ia bertemu penyanyi dangdut keliling Dona Satelit (Dian Sastrowardoyo) yang orkesnya bermarkas di Jakarta. Membongkar tabungannya, Huda memohon bantuan Dona untuk mencarikan lokasi ibunya, agar suatu saat bisa ia susul. Cerita segitiga antara Huda, Dona, dan ibu Huda membentuk semacam dongeng psikoanalisa yang malu-malu. Ada sosok ibu yang ditempiaskan Nurman di wajah Dona, ada raut harap-harap malu pada tatapan Huda, bahwa Dona adalah perempuan yang pantas ia berikan afeksi sebagai respon terhadap afeksinya yang tak terlampiaskan pada sosok ibu.

Sementara Huda kehilangan ibu, Rian (Yoga Pratama) adalah sosok yang kelebihan ibu. Ia menerima hadiah sebuah handycam mini dari ibunya berkat usaha studio foto warisan mendiang ayah mereka yang lumayan sukses. Suatu hari ibunya datang membawa lelaki baru yang akan ia nikahi. Dalam ketidaksepakatannya, Rian tak punya cara lain selain bermain dengan kameranya: merekam, bahkan mengintip anak dara kiai yang tengah menanggalkan jilbab. Rian akhirnya memilih untuk menyingkirkan gambar ibu dari kepalanya dan memfokuskan diri pada kemungkinan masa depan yang bisa ia raih dengan kamera kecilnya sebagai bekal. Seti- ap pasar malam, Rian mengunjungi Pak Toha, projeksionis layar tancap dimana ia bertanya segala sesuatu tentang mekansime sinema, cara pengambilan dan penayangan gambar-gambar berge- rak. Rian adalah anak pesantren yang cerita pahit keluarganya dilampiaskan lewat kecintaan lainnya pada sinema. Selain Rian, adapula Syahid (Yoga Bagus), teman mereka yang ditinggal mati ibunya dan sekarang bapaknya terkapar di ranjang rumah sakit. Sakit tambah parah, namun tak bisa dibawa pulang sebab keluarga Syahid tak sanggup menebus biaya rumah sakitnya, utang rumah sakit saja yang terus menumpuk. Syahid adalah orang yang sangat terganggu dengan keberadaan Amerika, ia percaya bahwa Amerika mewakili Yahudi kafir dan harus diperangi, perang melawan Yahudi memungkinkan Syahid untuk mati syahid, mati di jalan tuhan yang akan diganjar langsung dengan surga. Jikalau Huda bertungkus-lumus dengan polemik kekurangan ibu dan Rian berjuang melawan sindrom keberlebihan ibu, maka pola pikir syahid lebih dekat dengan kelompok pemegang teguh teori konspirasi, yang membimbingnya untuk selangkah lebih dekat dekat dengan kelompok Islam garis keras.

Bekal besar Nurman Hakim dalam 3 Doa 3 Cinta (2008) adalah jukstaposisi, baik gambar, suara, dan penempatan 
karakter. Film dibuka dengan para kiai mengaji Jawa, sebuah tradisi khas yang hanya dilakukan oleh madrasah-madrasah Islam di pulau Jawa dimana Kiai membacakan ayat Al-quran atau hadis sepenggal-sepenggal lalu mengartikannya ke dalam bahasa Jawa. Ayat yang dibacakan oleh sang Kiai adalah ayat "Takkan puas kaum yahudi dan nasrani sebelum kamu menjadi salah satu dari mereka," yang lalu kemudian disanggah sendiri oleh sang kiai, "Tapi bukan berarti umat islam harus memusuhi mereka." Dua wejangan yang dijukstaposisikan satu sama lain membuat adegan film menjadi sangat efektif. Jukstaposisi pertama adalah cara mengaji Islam Jawa yang merayakan Islam sebagai agama yang menyatu dengan budaya nusantara, sebentuk sanggahan cerdas pada narasi-narasi film mainstream pasca Soeharto (seperti Ayat-Ayat Cinta dan Ketika Cinta Bertasbih). Dalam 3 Doa 3 Cinta (2008), Islam Indonesia adalah Islam yang lain, Islam yang didukung oleh kekuatan budaya tersendiri, yang ayat-ayat Alqurannya tidak pernah steril dari pembacaan berdasar bekal kultural masing-masing penafsir. Ketika ayat di atas dibacakan, ada sanggahan dari sang kiai yang mengisyaratkan bahwa ayat ini adalah yang paling ramai disalahgunakan oleh kaum teroris. Ayat ini memang paling ramai digunakan oleh para penceramah agama di Indonesia dalam rangka menuding bahwa segala kesengsaraan umat sebenarnya lebih disebabkan oleh konspirasi yahudi dan nasrani ketimbang kelemotan umat Islam sendiri. Sanggahan Pak Kiai kemudian dibenturkan pada scene selanjutnya, ketika Syahid digambarkan tengah asyik mendengarkan radio yang memberitakan perjuangan HAMAS di Palestina.

Jukstaposisi ini memaksa Islam keluar dari relung nyaman layaknya yang mereka nikmati dalam film macam AyatAyat Cinta dan Ketika Cinta Bertasbih. Ruangan musholla dan asrama santri yang membuka film ternyata tidak steril dari kondisi-kondisi sosial yang membentuk dirinya. Bahwa ternyata, ritual vertikal tidak berada diluar muamalah melainkan berada di dalamnya. Jukstaposisi di awal film kemudian mengawali bentuk-bentuk lain yang serupa yang tersebar di sekujur tubuh film. Berikutnya, wacana Syahid untuk mati syahid di jalan tuhan ditabrakkan dengan adegan mengintip anak perempuan pak Kiai.

Ada pula satu adegan latihan qasidah dimana ternyata sang pelatih adalah seorang gay. 3 Doa 3 Cinta (2008) berhasil untuk mengangkat isu gay dan kepesantrenan tanpa mengerangkengnya ke dalam stereotip. Bahwa orangorang semacam itu ada dan film tidak berurusan dengan simpati atau antipati, melainkan berusaha memotret 
kondisinya sedetil mungkin. Dalam diri pelatih qasidah yang gay ini, duduk bersampingan nilai-nilai yang tidak pernah berani dipotret oleh-oleh film Islam manapun di Indonesia sejak Titian Serambut Dibelah Tujuh (1982). Dalam diri Kang Pelatih Qasidah, relijiusitas pesantren, orientasi seksual, dan obsesi asmaranya terhadap tokoh Zaki kembali dijukstaposisikan dengan sempurna.

Asrul Sani pernah memotret isu ini sekelebat dalam filmnya. Titian Serambut Dibelah Tujuh yang ditulis oleh Asrul menceritakan seorang guru yang datang ke desa untuk mengajar ilmu-ilmu agama dan sosial dasar. Ternyata desa yang didatanginya dipimpin oleh seorang kepala desa yang tak lagi sayang dengan istrinya, kini ia lebih banyak bermain dengan seorang lelaki "piaraan." Namun, alihalih membuat protagonisnya berkonsentrasi pada orientasi seksual macam ini, Titian Serambut Dibelah Tujuh justru memilih untuk menganalisa kondisi sosial masyarakat secara keseluruhan dengan memotretnya satu-persatu, LGBT hanya termasuk salah satu di dalamnya. Dalam memotret, Titian Serambut Dibelah Tujuh juga mengandalkan teknik jukstaposisi dan menyerahkan urusan berempati dan berantipati sepenuhnya pada penonton. Dalam 3 Doa 3 Cinta (2008), jukstaposisi praktek-praktek tersebut kemudian bertemu hanya dalam satu karakter. 3 Doa 3 Cinta (2008) tidak munafik seperti film-film bertemakan Islam lainnya pasca Orde Baru: bahwa ada fenomena sosial yang melingkupi Islam yang membuatnya tidak pernah mewujud sebagai agama yang steril dari campur tangan budaya. Islam di Indonesia berurusan dengan banyak sekali faktor sehingga kesepakatan-kesepakatan relijius yang sejatinya disepakati di Tanah Arab harus ditinjau kembali sebelum ia diterapkan di Nusantara.

Berikutnya, menarik untuk membandingkan bagaimana ibadah vertikal dipotret dalam film-film Islam pasca Orde Baru dan bagaimana potretan 3 Doa 3 Cinta (2008). Di awal film AyatAyat Cinta, ada adegan shalat dimana kamera hanya berkonsentrasi pada mata tokoh Fahri, bagaimana ia memusatkan pikiran pada tuhannya dan pada target-target hidupnya untuk sempurna. Dalam shalat, kekuatan sosial tiba-tiba sirna menyisakan Fahri berdua saja dengan tuhannya. Memang terdengar puitis, tapi apakah itu yang benar-benar terjadi? 3 Doa 3 Cinta (2008), di sisi lain, memotret banyak sekali faktor yang mempengaruhi ibadah seseorang. Ada sebuah adegan shalat di-mana seorang santri berzikir sambil colak-colek, ada adegan shalat shubuh di mana seorang santri yang mengantuk tak bisa bangkit dari sujudnya. Film ini bahkan sampai menyentuh adegan seksual yang 
dilakukan kiai yang adegannya tepat ditempatkan setelah sang kiai memimpin shalat di shot sebelumnya. 3 Doa 3 Cinta (2008) tidak pernah ingkar bahwa ibadah vertikal, seberapapun pentingnya, tetaplah hanya merupakan salah satu mata rantai kecil dalam keseluruhan sirkulasi hidup penganut agama, yang sangat dipengaruhi dan mempengaruhi faktor-faktor lainnya. Disandingkan dengan potret-potret ibadah ritualistik dalam 3 Doa 3 Cinta (2008), AyatAyat Cinta menjadi terkesan pengecut dengan lari berlindung ke dalam Islam personal yang egois dan reduksionistik. Pasalnya, Ayat-Ayat Cinta (Dan film-film Islam di Indonesia pasca Orde Baru) pada umumnya berusaha memasukkan paksa muamalah ke dalam lingkup ibadah vertikal, sementara 3 Doa 3 Cinta (2008) dengan kritis menyatakan bahwa justru ibadah vertikallah yang sebenarnya, secara alamiah, berada dalam lingkaran konsep muamalah. Seseorang yang beriman, menurut 3 Doa 3 Cinta (2008), tak bisa dipungkiri bahwa mereka tak jauh dari kegemaran terhadap James Bond, kegemaran menonton konser dangdut erotis, pengalaman naik kuda-kuda di pasar malam, menonton film horor, dan lain sebagainya. Interaksi antara agama dan persinggungan-persinggungan inilah yang kemudian membentuk pribadi seseorang. Islam tidak secara gegabah dipandang sebagai satu-satunya faktor yang membentuk pribadi protagonisnya, seorang muslim bukanlah seorang yang hitam putih.

\section{Ibu dan Konsep Rumah}

Dalam 3 Doa 3 Cinta (2008), sosok Ibu sangat penting bagi ketiga karakternya. Huda adalah seorang santri pencari ibu, Rian selalu bergulat dengan ibunya yang sangat getol mencari pengganti sosok ayahnya, sementara Syahid yang tanpa ibu cenderung lebih dekat pada kekerasan agama. Ibu adalah tanah lahir muasal se-tiap karakter dalam film. Namun, terdapat perbedaan bentuk hubungan antara konsep "Ibu" yang digeluti oleh Huda dan Ryan serta Syahid. Bagi Huda dan Ryan, sosok ibu adalah tanah muasal yang terus-menerus dinegosiasikan dan menjadi tujuan. Huda bernegesosiasi tanpa henti dengan imej tentang ibunya, paham betul bahwa ia harus kembali pada ibunya meskipun tak tahu benar dimana ia berada. Lewat tokoh Dona Satelit, pergulatan Huda untuk mendefinisikan dan bergerak ke arah ibunya menjadi konkret. Yang dicari oleh Huda adalah Rumah, atau meminjam istilah Hobsbawm, heimat. Heimat dapat diartikan sebagai rumah dimana seseorang seharusnya tinggal dan kembali setiap kali pergi. Yang membedakannya dengan konsep rumah (home) adalah bahwa home me- 
rupakan ruang homogen dan stabil yang sudah selesai dari segala macam negosiasi, sementara heimat adalah rumah yang harus dan akan terus menerus dinegosiasikan. Konsep ibu sebagai heimat-lah yang membuat narasi 3 Doa 3 Cinta berjalan. Semesta huda dipenuhi oleh kerinduan akan ibunya, segala macam piranti naratif lain hadir sebagai kendaraan Huda menuju ibunya. Semesta Ryan pun setali tiga uang, negosiasi dengan ibu dan rumah dimulai ketika sang ibu mengiriminya handycam yang sudah lama diidam-idamkannya. Ternyata, sang Ibu menyimpan maksud terselubung, ia menggunakan handycam itu untuk mempermulus dirinya mendapatkan restu Ryan untuk menikah lagi. Ryan pun bernegosiasi, ia tak rela sang ibu menikah lagi, tapi juga tak mau memberikan handycam itu kembali. Ryan lari dari "kenyataan" dengan sering-sering mengunjungi Pak Toha, seorang juru proyektor di layar tancap Pasar Malam.

Konsep Rumah dalam 3 Doa 3 Cinta (2008) tidak lantas berhenti di Ibu, ia juga berusaha menampilkan kondisi sosial sekitar pesantren sebagai heimat yang terus menerus dinegosiasikan lewat jukstaposisi sebagai metode utamanya. Pelatih Qasidah yang gay akhirnya diusir dari pesantren tapi tentu saja tidak diusir dari masyarakat. Beberepa sindiran juga secara verbal dilontarkan lewat dialog, "Sholat gak perlu kayak gitu, emangnya di Arab?" atau "Romo tidak selalu benar," dan lain sebagainya. Dalam film tentang Islam pasca-Soeharto pada umumnya, ruang publik bernafaskan Islam dibangun dengan mengeksklusi kelompok-kelompok liyan (fremde, dalam bahasa Hobsbawm). Dalam Ayat-Ayat Cinta, pernikahan antara Maria dan Fahri menjadi mungkin dan barokah karena Maria pada akhirnya masuk Islam. Atributnya sebagai seorang koptik ditanggalkan, menghapus pangkat-pangkat liyan dan kemudian menjadi Islam. 3 Doa 3 Cinta (2008) menghindarkan diri dari tindak eksklusi kelompok manapun. Bahwa gay dan lesbian dilarang dalam Islam dan tabu dalam kehidupan pesantren, tak dapat dipungkiri. Namun tak dapat dipungkiri pula bahwa keberadaan orang-orang semacam itu tak dapat dihapus dan sudut pandang Islam bukanlah satu-satunya sudut pandang yang boleh menjustifikasi posisi sosial mereka. Seorang seperti Dona Satelit akan dipandang sebagai yang liyan sebab ia tak menjalankan syariat agama (membuka aurat dan bergoyang seronok), tapi ia kemudian tidak disentuh oleh doktrin-doktrin agama, apalagi dieksklusi dari ruang heimat yang cair dan terus bergerak.

3 Doa 3 Cinta berhasil sebagai salah satu film tentang Islam yang paling kritis dan relevan pada era pasca-Seoharto 
karena alih-alih mengambil jalur munafik dengan mengatakan bahwa Islam adalah satu-satunya tipe ruang publik relevan di negara multikultur dan multiagama seperti Indonesia, ia memilih untuk memotret ruang publik muslim sebagai hanya salah satu dari ruang publik yang mungkin dan sah untuk diejawantahkan. Pun pada penutupnya, 3 Doa 3 Cinta (2008) tetap mengakui bahwa cerita-cerita seperti yang dialami Huda sangat mungkin terjadi: seorang yang terhalang untuk kembali ke heimat-nya (karena satu dan lain alasan) memilih kembali ke pesantren dan melanjutkan tampuk kepesentranan, melanjutkan supremasi ruang publik Islam di dalam dan di sekitar madrasah. Sebuah pesimisme? Mungkin saja. 3 Doa 3 Cinta (2008) juga memotret tarik-menarik tensi dalam interaksi antara ru-ang publik Islam dan ruang publik lain serta alih-alih mempopulerkan doktrin-isasi ayat yang diikuti "cocoklogi," ia menampilkan dengan cermat implikasi-implikasi dari kenyataan bahwa agama adalah praktek sosial yang inheren.

\section{Islam Impor dan Islam}

\section{Lokal}

Dinamika islam di ruang publik sejak 3 Doa 3 Cinta (2008) bergerak sangat cepat, kelompok kepentingan seperti FPI (Front Pembela Islam) dan
FUI (Forum Umat Islam) berperan besar dalam mengampanyekan ruang publik berbasis hukum Islam di Indonesia. Mereka bahkan tak segan-segan melakukan kekerasan bilamana tuntutan mereka tidak digubris pemerintah. Ada dua sumber yang kerap digunakan oleh kelompok semacam FPI dan FUI untuk mengesahkan kekerasan yang mereka lakukan. Pertama, butir pertama dalam Pancasila (Lima butir pokok ideologi negara) yang berbunyi "Ketuhanan yang Maha Esa," menurut mereka, penyelenggaraan negara di Indonesia tidak boleh berjalan bertentangan dengan apa yang telah digariskan tuhan, di mata mereka, Islam. Kedua, mereka mengutip salah satu dalil yang berasal dari perkataan Nabi Muhammad yang sekurang-kurangnya berbunyi, "Bila kau melihat kemungkaran, maka ubahlah dengan tanganmu. Bila tak bisa, ubahlah dengan lisanmu. Bila tak bisa pula, ubahlah dengan hatimu, niscaya itulah selemah-lemahnya iman.” Pada bulan puasa contohnya, ormas semacam FPI dan FUI menganggap bahwa warung makan yang buka pada siang hari adalah kemungkaran dan tidak sejalan dengan yang digariskan oleh yang kuasa sehingga harus ditindak. Cara menindak yang paling besar keutamaannya adalah lewat "tangan": dengan datang langsung ke warung dan menyeru pemilik warung untuk tutup, bila terjadi 
adu mulut, sangat sering mereka respon de-ngan kekerasan fisik. Promosi kekerasan di ruang publik telah membawa terorisme bergeser menjadi setingkat lebih menakutkan. Seri bom bali tentu masih segar bagi publik antarbangsa, teror semacam bom bali adalah kekerasan yang dilakukan secara gerilya dan "hanya" menampilkan hasil kekerasan tersebut sembari menyembunyikan prosesnya. namun dalam kasus FPI dan FUI, tidak hanya mendemonstrasikan kekerasan, mereka juga terang-terangan mempromosikan tafsir-tafsir ideologis untuk melegitimasi kekerasan tersebut beserta arak-arakan prosesnya.

Tidak hanya ideologi politik, anggota ormas semacam FPI dan FUI juga biasanya tampil dengan mengenakan jubah dan surban, mereka dipimpin oleh para Habib (cendekiawan agama yang diyakini adalah keturunan langsung Nabi Muhammad). Mereka berpakaian layaknya orang arab, dan sedikit banyak menggunakan istilah sehari-hari dalam bahasa arab, seperti "Ukhti” (Saudari) dan Akhi (Saudara). Dalam hal berpakaian, kebiasaan FPI dan FUI beririsan dengan gerakan muslim lain seperti Jamaah Tabligh. Jamaah Tabligh adalah ormas muslim lain yang meskipun tidak besentuhan dengan politik, tapi sangat-sangat konservatif dalam mempertahankan adab-adab ibadah islam klasik. Mereka melakukan amalan-amalan bersifat tak wajib yang sering dilakukan oleh nabi Muhammad, seperti memelihara janggut dan menyuap makanan dengan tiga jari, berbagi makanan di baki. Khalifah adalah film yang menyoroti kedua permasalahan ini.

Khalifah dibuat dengan gaya minimalis, cat rumah terlihat tak disentuh ulang, perabotan set seadanya, dan kamera yang tidak segenit film-film lainnya. Seorang perempuan bernama Kha- lifah, dengan motivasi yang berpendar di antara keengganan untuk menikah dan perasaan bersalah karena tak bisa membiayai ayahnya, akhirnya menerima lamaran Rasyid, seorang lelaki taat yang direkomendasikan oleh kawan ayahnya. Rasyid adalah pedagang produk-produk Arab yang harus sering bepergian untuk berjaja sehingga jarang di rumah. Karena ketaatan agama Rasyid, Khalifah yang tadinya tidak memakai jilbab perlahan mengenakan jilbab. Tante Rita, bos Khalifah juga tak keberatan jika ia datang bekerja memakai jilbab. Masalah utamanya muncul ketika Kha- lifah keguguran bayi pertamanya, dan Rasyid menyalahkan semuanya pada Khalifah, ia menuding bahwa cara berpakaian Khalifah yang masih kurang tertutup menyebabkan kandungannya digugurkan oleh Tuhan. Khalifah ak- hirnya bercadar. Meskipun Tante Rita tampak berat hati, ia masih memberikan kesempatan Khalifah untuk bekerja di salon 
dengan membuat hari-hari khusus yang hanya boleh melayani pelanggan perempuan. Dalam definisi Rasyid, keimanan Khalifah naik drastis dari seorang penganut Islam setengah-setengah yang tak mengenakan atribut relijius apapun menjadi perempuan yang menganut Islam secara keseluruhan karena cadarnya yang sekarang rapat. Namun dalam definisi personalnya, Khalifah memakai atribut relijius tersebut lebih disebabkan karena suaminya dibandingkan taraf keberagamaannya sendiri. Atribut relijius yang dikenakan oleh Khalifah, alih-alih menjadi identitas yang kuasa merepresentasikan keimanannya, sebenarnya adalah kuasa penjajahan atas tubuh dan kemerdekaan pribadinya. Lebih jauh lagi, ada pertanyaan penting yang dilontarkan oleh Khalifah: apakah benar bahwa cadar adalah atribut relijius? Atau sekedar kebiasaan kultur orang Arab yang diserap membabi buta oleh orang Islam di Indonesia? Dari situ, Khalifah berhipotesis bahwa ada gap yang tak bisa dibedakan oleh umat Islam di Indonesia dewasa ini, yakni gap antara islam sebagai "agama murni" dan Islam sebagai "budaya impor yang dibaca sebagai agama." Untuk memper tajam pertanyaan itu, sebagian besar atribut sinematik dalam Khalifah dibuat berhubungan dengan budaya arab. Rasyid adalah penjaja produk-produk Arab, Khalifah berkenalan dengan seorang pemakai cadar yang ternyata memakai cadar karena dulu pernah tinggal di Arab, ia kedatangan tetangga baru yang akhirnya berangkat menjadi TKI di Arab Saudi, bahkan, musik yang digarap Djaduk Ferianto pun menggunakan notasi-notasi padang pasir. Tampak sangat jelas usaha Nurman Hakim untuk menunjukkan mana yang Arab dan mana yang Islam dan bagaimana keduanya harus berinteraksi untuk menunjukkan Islam yang benar-benar agamis dan bukan sekedar copy-paste budaya luar. Kecenderungan ini juga menampar keras para cendekiawan kolot anti-barat dengan dalih bahwa barat adalah imperialisme budaya asing. Dalam Khalifah yang minimalis, nyata, dan sederhana, budaya arab pun ternyata adalah imperialisme budaya asing yang sama saja dampaknya bagi masyarakat nusantara. Bahkan lebih licik sebab ia datang berbungkus topeng agama dan kebaikan tuhani.

Setelah mencapai derajat keimanan yang benar-benar diinginkan oleh Rasyid, Khalifah mengalami masalah baru. Dirinya yang sama sekali tidak punya alasan lain mengenakan cadar - selain karena suaminya - mulai mengalami perlakuan kasar dari orang-orang di sekelilingnya. Ia dituduh teroris. Interaksi yang terjadi antara Khalifah dan orangorang yang menuduhnya tero- ris terbilang unik. Dalam adegan-adegan terse- 
but, Khalifah dipotret seperti korban, bahwa ia yang tak tahu apa-apa harus menghadapi segala macam stereotip hanya karena atribut relijiusnya. Tapi di balik itu, penting diperhatikan bahwa Khalifah disetir oleh orang lain. Alih-alih sebagai korban, sadar atau tidak, Khalifah sebenarnya adalah medium konservatisme itu sendiri. Ada semacam hubungan segitiga antara Khalifah, Rasyid, dan orang-orang lain di sekitar mereka. Dan Khalifah sebagai medium, ironisnya, adalah orang yang paling tidak mengerti apa yang sebenarnya sedang terjadi. Pada adegan ketika pertama kali ia mengenakan cadar, sudut pandang Khalifah ditampilkan lewat teknik kamera POV beserta suara desah nafasnya yang tidak nyaman, asing dengan apa yang baru saja dilakukannya. Posisi pemeluk agama sedang dipermainkan oleh konsumsi yang membabi buta terhadap produk-produk budaya arab.

Seperti 3 Doa 3 Cinta (2008), Nurman Hakim tak pernah menunjukkan telunjuknya pada sesuatu secara langsung untuk menyampaikan maksud, melainkan menggunakan metode jukstaposisi. Selain musik arab yang terus-terusan mengiringi drama bersetting lokal, cadar juga didamping-dampingkan dengan salon, tempat dimana orang mesti membuka aurat untuk menerima pelayanan, yang standar maupun yang plus-plus. Dari metode jukstaposisi ini, tersam- paikan maksud konsep yang diusung oleh Nurman Hakim, dimana Islam adalah praktek yang tidak pernah homogen, selalu ada berbagai model Islam yang alih-alih musti ditabrakkan, justru didampingkan saja olehnya untuk kemudian dilihat sendiri oleh penonton. Khalifah adalah percobaan selanjutnya yang, melanjutkan 3 Doa 3 Cinta (2008), berfungsi sebagai model sistem sosial yang telah diselinapi oleh pengaruh Islam.

Meski demikian, Khalifah juga tidak sentosa dari stereotip. Pada tokoh Rasyid dapat kita amati berbagai atribut yang ditempel-tempelkan saja demi melengkapi karikatur para aktivis garis keras, motif ekonomi, dan ekspresi politik mereka. Rasyid seolah-olah adalah agen Islam Arab yang sempurna yang kemudian dihitam-putihkan dengan Khalifah sang protagonis. Di tengah konsentrasinya yang begitu detil pada jukstaposisi adegan dan sekuen, Khalifah justru luput dalam memperhatikan jukstaposisi dalam karakter-karakter utamanya.

Dalam rumah tangga Rasyid dan Khalifah dapat kita jumpai hubungan kuasa (power relation) dimana budaya Arab berkuasa atas budaya pribumi tanpa bisa dibantah oleh sang pribumi sebab budaya arab ditempelkan senantiasa dengan agama. Bahwa minyak angin Arab disarankan Rasyid pada Khalifah yang sakit perut, bahwa per- 
madani bergambarkan Ka'bah dipajang di dinding rumah, dan lain sebagainya. Ini tentu lebih laten dari kenangan kolonial Belanda dan Jepang sebagai wujud budaya asing yang berembrio pada motif ekonomi, yang pengamatan atasnya senantiasa ditinjau pada level Repressive State Apparatus (setidaknya seperti yang dibangun dalam wacana se-jarah Indonesia). Khalifah menjadi semesta kecil dimana Islam, ketika ia tak dapat dipisahkan dari latar kebudayaannya, berpotensi menjadi budaya baru dan sama sekali lain. Khalifah menyentakkan kita akan fakta bahwa budaya arab di Indonesia telah sebegitu luasnya dilanggengkan oleh motif-motif agama. Pada akhirnya kedua macam budaya yang masuk ke Indonesia sejak era kolonialisme ini berujung pada penguasaan ruang publik. Kolonialisme memang bukan obyek teropong Nurman Hakim, ia lebih memilih untuk mengamati gencarnya invasi Islam berbau arab terhadap ruang publik yang dilancarkan pada era mutakhir ini, tidak jarang lewat kekerasan yang didalangi oleh ideologi-ideologi komunitarian, sebuah penolakan atas metode jukstaposisi berfikir. Lewat sinema, Nurman Ha-kim mengingatkan kita kembali pada kemungkinan jukstaposisi itu, pada ke- mungkinan kembali kepada kebhinekaan tanpa harus lewat tangan-tangan letoy pemerintah: kebhinekaan adalah cara berfikir dan cara melihat, dan itu su-dah berhasil diterapkan Nurman hingga ke level bahasa sinemanya.

Akhirnya, izinkan saya memberi pause pada diskusi ini dengan sebuah ujaran Yasmin Ahmad: kita bisa menjadi benar tanpa harus menjadi satu-satunya. Praktik Islam di Indonesia, seperti apapun bentuknya, bisa saja menjadi benar, tapi tidak mungkin menjadi satu-satunya. Nurman Hakim memotret itu dalam jukstaposisi yang sebenarnya adalah hakikat sinema: montase yang sudahlah itu intellectual montage, montage of attraction, atau apapunlah nama-nama yang dari Eropa itu. Yang jelas, film-film Nurman memberikan kita, lewat bahasa sinema, semacam sentakan listrik dalam pikiran, a shock of thought tentang kondisi yang mengitari kita sendiri. 